\title{
Purification of High Molecular Weight Kininogen and the Role of This Agent in Blood Coagulation
}

\author{
HIDEHIKO SAITO \\ From the Department of Medicine, School of Medicine, Case Western Reserve University and \\ University Hospitals of Cleveland, Cleveland, Ohio 44106
}

A B S T RACT Recent studies of individuals with high molecular weight (HMW) kininogen deficiency established the importance of this plasma protein for in vitro initiation of blood coagulation. In the present study, HMW-kininogen was highly purified from human plasma by monitoring its clot-promoting activity, using Fitzgerald trait plasma as a substrate. This preparation of HMW-kininogen revealed a single band on sodium dodecyl sulfate-polyacrylamide gel electrophoresis (mol wt: 120,000) and released $1 \%$ of its weight as bradykinin upon incubation with plasma kallikrein. HMW-kininogen specifically repaired impaired surface-mediated plasma reactions of Fitzgerald trait plasma, but did not affect those of Hageman trait and Fletcher trait plasma. Kinin release from HMW-kininogen by trypsin, but not by plasma kallikrein, resulted in total loss of clotpromoting activity. No inhibitors of coagulation were found when all kinin activity was removed from HMW-kininogen by trypsin. The roles of HMWkininogen, Hageman factor (HF, Factor XII), plasma prekallikrein (Fletcher factor), and plasma thromboplastin antecedent (PTA, Factor XI) in blood coagulation were studied in a purified system. HMWkininogen was absolutely required for activation of PTA by HF and ellagic acid. The yield of activated PTA was proportional to the amount of HF, HMWkininogen, and PTA in the mixtures, suggesting that, to activate PTA, these three proteins might form a complex in the presence of ellagic acid. No fragmentation of HF was found under these conditions. In contrast to HF, HF-fragments (mol wt: 30,000) activated PTA in the absence of HMW-kininogen and ellagic acid. Thus, it appears that in the present study PTA was activated in two distinct ways. Which

\footnotetext{
A preliminary report of this study was presented at the Central Society for Clinical Research on 4 November 1976 in Chicago, Ill. 1976. Clin. Res. 24: 573A. (Abstr.)

Received for publication 11 October 1976 and in revised form 6 April 1977.
}

pathway is the major one in whole plasma remains to be determined.

\section{INTRODUCTION}

When normal human plasma comes into contact with negatively charged surfaces such as glass, several plasma reactions, including blood coagulation, fibrinolysis, and kinin generation, may take place. Studies of Hageman trait plasma have shown the central role of Hageman factor (Factor XII) as a common trigger of these reactions (1-3). A further elucidation of the interrelationships among various surface-mediated plasma reactions has come about from the recent discovery of Fletcher trait (4) and Fitzgerald trait $(5,6)$. Both conditions were initially described as blood-clotting abnormalities; the plasmas of affected individuals were said to be deficient in Fletcher factor and Fitzgerald factor, respectively. Subsequently, both conditions were also associated with abnormal in vitro fibrinolysis and kinin generation. Fletcher factor is a plasma prekallikrein (7-9). An agent functionally deficient in Fitzgerald trait and other plasmas with the same clotting defect was recently identified as high molecular weight $(\mathrm{HMW})^{1}$ kininogen (10-14). Thus, these studies established that plasma prekallikrein and HMW-kininogen, proteins of the plasma kinin-forming system, also participate in blood coagulation in vitro.

The site and mode of action of HMW-kininogen in clotting is not fully understood, but this agent appears to participate early in the intrinsic pathway of thrombin formation (12). The present paper describes the purification of HMW-kininogen and its role in blood coagulation.

\footnotetext{
${ }^{1}$ Abbreviations used in this paper: HF, Hageman factor; HMW, high molecular weight; PTA, plasma thromboplastin antecedent; PTT, partial thromboplastin time; SDS, sodium dodecyl sulfate.
} 


\section{METHODS}

Fletcher trait and Fitzgerald trait plasmas were kindly supplied by Dr. C. Abilgaard, University of California at Davis and Dr. R. Waldmann, Henry Ford Hospital, Detroit, Mich.

HMW-kininogen was prepared from normal human plasma by a modification of published methods $(15,16)$. During purification, Fitzgerald factor activity was identified by a clotpromoting assay (12), $1 \mathrm{U}$ being arbitrarily defined as that amount present in $1 \mathrm{ml}$ of normal pooled plasma. The sample was diluted more than 20 -fold in barbital-saline buffer. The kininogen content of our preparations was also monitored as described previously (17).

Step 1. Batch absorption and elution from quaternary aminoethyl-(QAE) Sephadex. $2 \mathrm{U}$ of blood was collected into polystyrene bottles containing $0.02 \mathrm{vol}$ of $0.5 \mathrm{M}$ sodium citrate ( $\mathrm{pH} 5.0$ ) and $50 \mathrm{mM}$ benzamidine $\mathrm{HCl}$ (Eastman Kodak Co., Rochester, N.Y.). To $\cong 500$ ml plasma was added 0.01 vol of $0.01 \mathrm{M}$ EDTA and 5 mg of hexadimethrine bromide (Polybrene, Aldrich Chemical Co., Inc., Milwaukee, Wis.) per ml. The plasma was adsorbed with 0.02 vol of alumina C $\gamma$-gel (Calbiochem, San Diego, Calif.) for $10 \mathrm{~min}$ at room temp. After centrifugation, the supernatant plasma was dialyzed overnight against two changes of $10 \mathrm{vol}$ of $0.025 \mathrm{M}$ Tris- $\mathrm{HCl}$ buffer ( $\mathrm{pH} 7.5$ ) containing $0.1 \mathrm{M} \mathrm{NaCl}, 0.1 \mathrm{mM}$ EDTA, $1 \mathrm{mM}$ benzamidine, $0.05 \mathrm{mg}$ Polybrene $/ \mathrm{ml}$, and $0.02 \%$ sodium azide. The dialyzed plasma was mixed for $45 \mathrm{~min}$ at room temp with $\cong 800$ $\mathrm{ml}$ settled volume of QAE-Sephadex A-50 (Pharmacia Fine Chemicals, Div. of Pharmacia Inc., Piscataway, N.J.) equilibrated with the buffer described. The mixture was allowed to settle, the supernatant plasma was discarded, and the settled gel was mixed with fresh buffer and poured into a plastic column (5-cm diameter), and the column was washed with the same buffer for 2 days. At this step, HMWkininogen, attached to the gel, was completely separated from plasma thromboplastin antecedent (PTA, Factor XI) and plasma prekallikrein (Fletcher factor). The washed QAESephadex A-50 gel was transferred to a beaker and was eluted four times with $300 \mathrm{ml}$ each of $0.025 \mathrm{M}$ Tris-Cl buffer ( $\mathrm{pH} 7.5$ ) containing $0.5 \mathrm{M} \mathrm{NaCl}$ and EDTA-benzamidine-Polybrene-sodium azide, and the eluates with Fitzgerald factor clotting activity were combined. After addition of benzamidine to a final concentration of $2 \mathrm{mM}$, material was precipitated by the addition of solid ammonium sulfate to $60 \%$ saturation.

Step 2. QAE-Sephadex column. The precipitate was dissolved in $0.025 \mathrm{M}$ Tris-Cl buffer ( $\mathrm{pH} 7.5$ ) containing $0.1 \mathrm{M}$ $\mathrm{NaCl}$-EDTA-benzamidine-Polybrene-sodium azide, dialyzed against the same buffer, and applied to a column of QAESephadex A-50 $(2.5 \times 38 \mathrm{~cm})$, previously equilibrated with the same buffer. Protein was eluted with a linear salt gradient of $500 \mathrm{ml}$ each of the equilibrating buffer and $0.025 \mathrm{M}$ Tris-Cl buffer ( $\mathrm{pH}$ 7.5) containing 0.5 M NaCl-EDTAbenzamidine-Polybrene-sodium azide. HMW-kininogen was eluted between 0.3 and $0.4 \mathrm{M} \mathrm{NaCl}$, separated from Hageman factor (HF, Factor XII) activity which was eluted before a concentration of $0.25 \mathrm{M} \mathrm{NaCl}$ was reached. The HMW-kininogen-rich fractions were pooled and, after the addition of benzamidine to $2 \mathrm{mM}$, solid ammonium sulfate was added to $60 \%$ saturation. The precipitate was frozen at $-20^{\circ} \mathrm{C}$, and the same procedures (steps 1 and 2 ) were repeated with an additional $4 \mathrm{U}$ of blood.

Step 3. Gel filtration on Ultragel and Sephadex G-200. The precipitate from $6 \mathrm{U}$ of blood was dissolved in $0.1 \mathrm{M}$ Tris-Cl buffer ( $\mathrm{pH} 7.5$ ) containing $0.2 \mathrm{M} \mathrm{NaCl}$-benzamidinePolybrene-sodium azide and dialyzed against the same buffer. The dialyzed solution $(23 \mathrm{ml})$ was divided into two parts, and each part was filtered through a $2.6 \times 89-\mathrm{cm}$ silicone-coated glass column of Ultragel AcA 34 (LKBProdukter AB, Bromma, Sweden) that had been preswollen in the same buffer; approximately $11-\mathrm{ml}$ fractions were collected at a flow rate of $10 \mathrm{ml} / \mathrm{h}$. The peak tubes were pooled and, after benzamidine was added to $2 \mathrm{mM}$ final concentration, solid ammonium sulfate was added to $60 \%$ saturation. The resultant precipitate from two runs $(\cong 7 \mathrm{ml})$ was dissolved and dialyzed against the above buffer. Diisopropylfluorophosphate (Sigma Chemical Co., St. Louis, Mo.) in 1,2dipropyl alcohol was added to the dialyzed solution to a final concentration of $0.02 \mathrm{M}$, and the mixture was incubated overnight at room temp (16). The solution was then filtered through a $2.5 \times 87-\mathrm{cm}$ column of Sephadex G-200 equilibrated with the buffer described. The HMW-kininogen-rich fractions were pooled, concentrated by ammonium sulfate precipitation, dissolved, and dialyzed against $0.05 \mathrm{M}$ sodium acetate buffer ( $\mathrm{pH}$ 6.2) containing $0.125 \mathrm{M} \mathrm{NaCl}$ and $1 \mathrm{mM}$ benzamidine. All procedures up to this point were performed at room temperature.

Step 4. Carboxymethyl-(CM-)Sephadex column. The dialyzed solution was applied to a $2.5 \times 14-\mathrm{cm}$ siliconecoated glass column of CM-Sephadex C-50 equilibrated with the same buffer. Protein was then eluted with a linear salt gradient of $250 \mathrm{ml}$ each of the equilibrating buffer and the same buffer with $0.7 \mathrm{M} \mathrm{NaCl}$ (Fig. 1). 6-ml fractions were collected, and HMW-kininogen was eluted at a concentration of $\mathrm{NaCl}$ between 0.3 and $0.4 \mathrm{M}$. Fitzgerald factor clotting activity showed only a single peak and was not separated from kininogen in these fractionation procedures. On the CM-Sephadex C-50 column, peaks of protein, kininogen, Fitzgerald factor clotting activity, and the ability to repair impaired fibrinolysis all eluted at the same place. Tubes containing the peak activities were pooled, dialyzed against barbital-saline buffer $(\mathrm{pH} 7.4)$, and frozen at $-70^{\circ} \mathrm{C}$. The yield was $\cong 15 \%$, the preparations' specific activity was $17 \mathrm{U} / \mathrm{mg}$ protein in a clot-promoting assay, and it released $\cong 1 \%$ of the weight of protein as bradykinin when treated with trypsin or plasma kallikrein. Upon analytical polyacrylamide gel electrophoresis (18), two protein bands were stained by Coomassie Blue, both of which had Fitzgerald factor clotting activity as tested upon segments of replicate gels. Upon sodium dodecyl sulfate (SDS)-polyacrylamide gel electrophoresis (19), this preparation revealed a sharp single band with an approximate mol wt of 120,000 . Protein standards employed were: bovine pancreatic chymotrypsinogen A, 25,000 (Pharmacia Fine Chemicals); pepsin, 35,000 (Worthington Biochemical Corp., Freehold, N.J.); human serum albumin, 68,000; type I bovine thyroglobulin, 160,000; Escherichia coli $\beta$-galactosidase, 135,000 (all from Sigma Chemical Co.); and human transferrin, 88,000 (BehringWerke A.G., Marburg, Germany).

Purified clotting factors, antibodies against clotting factors and procoagulant assays of $\mathrm{HF}, \mathrm{PTA}$, and plasma prekallikrein were prepared or performed as described earlier $(4,20-22)$. One unit of the procoagulant activity was arbitrarily defined as that amount present in $1 \mathrm{ml}$ of a standard pooled plasma. Two preparations of PTA were used; partially purified $(52 \mathrm{U} / \mathrm{mg}$ protein) and highly purified $(200 \mathrm{U} / \mathrm{mg}$ protein). The major contaminant of the former preparation was IgG, but both preparations, tested at $4 \mathrm{U} / \mathrm{ml}$ were free of any detectable activity attributable to $\mathrm{HF}$, prekallikrein, HMWkininogen, plasminogen, and plasmin. The highly purified PTA had an apparent mol wt of 160,000 on SDS gel electrophoresis. A preparation of $\mathrm{HF}$ (59 U/mg protein) was free of detectable activity attributable to other clotting factors $(<0.01 \mathrm{U} / \mathrm{ml})$ when tested at $8 \mathrm{U} / \mathrm{ml}$. It showed a single 


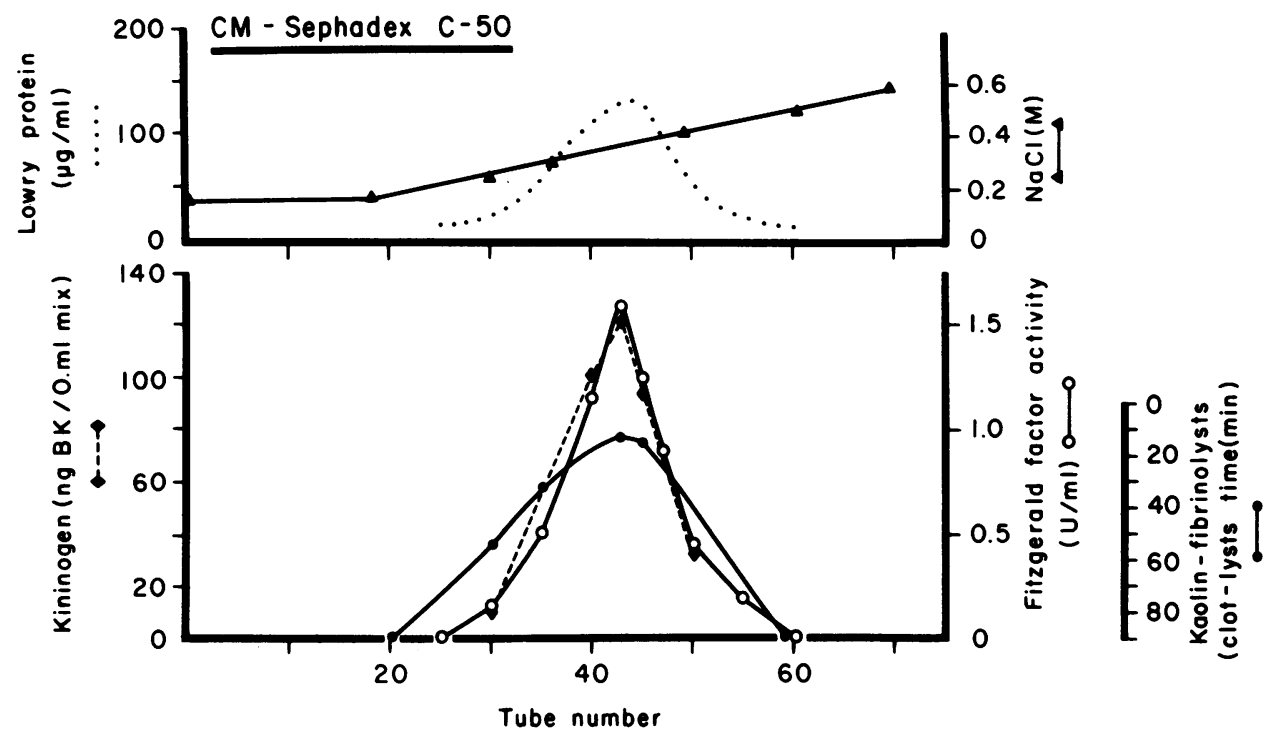

FIgURE 1 The chromatography of HMW-kininogen on a CM-Sephadex C-50 column. 154-ml HMW-kininogen fraction (284 U) was applied to a $2.5 \times 14-\mathrm{cm}$ column of CMSephadex C-50 equilibrated with $0.05 \mathrm{M}$ sodium acetate buffer ( $\mathrm{pH} 6.2$ ) containing $0.125 \mathrm{M}$ $\mathrm{NaCl}$ and $1 \mathrm{mM}$ benzamidine. Protein was eluted with a linear salt gradient of $250 \mathrm{ml}$ each of equilibrating buffer and the same buffer with $0.7 \mathrm{M} \mathrm{NaCl}$. 6-ml fractions were collected. The upper panel shows the concentration of protein and $\mathrm{NaCl}$; the lower panel shows Fitzgerald factor clotting activity, kaolin-induced fibrinolysis, and kininogen content, released as bradykinin (BK).

band on SDS gel electrophoresis (mol wt: 85,000). HF-fragments were prepared from purified HF by Enzite-trypsin (Miles Laboratories Inc., Miles Research Products, Elkhart, Ind.) digestion followed by gel filtration on Sephadex G-150. Its molecular weight by gel filtration was $\cong 30,000$, and on analytical polyacrylamide gel, it showed three prealbumin protein bands, all of which were associated with the prekallikrein-activating activity. Plasma kallikrein had a specific activity of $304 \mu \mathrm{mol} \mathrm{MeOH} / \mathrm{mg}$ per $\mathrm{h}$ in a $p$-toluene sulfonyl$\mathrm{L}$-arginine methyl ester esterase assay and was free of detectable plasmin or activated PTA activity. Plasma prekallikrein was prepared by QAE-Sephadex batch elution of plasma and sequential chromatography on QAE-, CM-, and Sephadex G-150, Sepharose-soybean trypsin inhibitor, and Sepharoseanti-human IgG (Sepharose, Pharmacia Fine Chemicals). It had a specific activity of $8 \mathrm{U} / \mathrm{mg}$ protein in Fletcher factor clotting assay and contained no detectable activity attributable to HF, HMW-kininogen, kallikrein, and plasmin. It had $0.03 \mathrm{U} / \mathrm{ml}$ of PTA activity at $1 \mathrm{U} / \mathrm{ml}$. When fully activated with trypsin, it hydrolyzed $625 \mu \mathrm{mol} \mathrm{MeOH} / \mathrm{mg}$ per $\mathrm{h}$ in a $p$-toluene sulfonyl-L-arginine methyl ester esterase assay.

The presence of plasma prekallikrein in the preparations of HF, PTA, and HMW-kininogen was also tested by a radioimmunoassay that can quantitatively measure as little as $0.003 \mathrm{U} / \mathrm{ml}$ (23). Prekallikrein antigen was absent by this assay in the plasma of a patient with Fletcher trait, and there was a good correlation (coefficient $=0.71$ ) between radioimmunoassays and clotting assays of 40 normal plasmas.

Antibodies against HF, PTA, and HMW-kininogen were crude IgG fraction of rabbit antiserum. They were functionally and immunologically monospecific. IgG fraction from normal rabbit serum was used as a control.

Kaolin-induced fibrinolysis (8), kinin-like activity (8), and the effect of incubating plasma with kaolin at $0^{\circ} \mathrm{C}(12)$ upon the Thrombotest time were studied as reported previously.

The effect of trypsin and plasma kallikrein upon HMWkininogen was studied by incubating $1 \mathrm{ml} \mathrm{HMW-kininogen}$ ( $2 \mathrm{U} / \mathrm{ml}, 0.115 \mathrm{mg}$ protein $/ \mathrm{ml}$ ) with $0.08 \mathrm{ml}$ of either bovine trypsin $(0.1 \mathrm{mg} / \mathrm{ml}$, twice-crystallized, dialyzed salt-free and lyophilized, Worthington Biochemical Corp.) or human plasma kallikrein $(0.17 \mathrm{mg} / \mathrm{ml})$ or barbital-saline buffer in a $12 \times 75-\mathrm{mm}$ polystyrene tube at $37^{\circ} \mathrm{C}$. At various intervals, $0.16-\mathrm{ml}$ aliquots were transferred to $10 \times 75-\mathrm{mm}$ polystyrene tubes containing $0.04 \mathrm{ml}$ soybean trypsin inhibitor $(0.1$ $\mathrm{mg} / \mathrm{ml}$, Worthington Biochemical Corp.) and $0.02 \mathrm{ml} 0.01 \mathrm{M}$ $o$-phenanthroline (Fisher Scientific Co., Inc., Pittsburgh, Pa.). 0.07- $\mathrm{ml}$ aliquots of these mixtures were subjected to analytical disc-gel electrophoresis, $0.01-0.03 \mathrm{ml}$ were used for assay of kinin, and the rest was used for HMW-kininogen clotting assays after appropriate dilution in barbital-saline buffer. HMW-kininogen incubated with buffer was used as a control.

The activation of PTA in a purified system was studied by incubating $0.075 \mathrm{ml}$ PTA $(0.023-0.2 \mathrm{U} / \mathrm{ml})$ with 0.025 $\mathrm{ml} \mathrm{HF} \mathrm{(0.01-1.8} \mathrm{U/ml),} 0.025 \mathrm{ml}$ prekallikrein $(0.1 \mathrm{U} / \mathrm{ml})$, $0.025 \mathrm{ml}$ HMW-kininogen $(0.0025-1 \mathrm{U} / \mathrm{ml})$, and $0.075 \mathrm{ml}$ ellagic acid (synthesized by Dr. J. Crum, Case Western Reserve University or obtained from $\mathrm{K} \& \mathrm{~K}$ Laboratories, Inc., Plainview, N.Y., 0.1-0.001 mM in barbital-saline buffer) in a $10 \times 75-\mathrm{mm}$ polystyrene tube at $37^{\circ} \mathrm{C}$. In some experiments, $0.02 \mathrm{ml} \mathrm{kaolin}(2 \mathrm{mg} / \mathrm{ml})$ was used instead of ellagic acid. At intervals, $0.05-\mathrm{ml}$ aliquots were transferred to prewarmed $10 \times 75-\mathrm{mm}$ polystyrene tubes containing $0.1 \mathrm{ml}$ Centrolex O (Central Soya Co., Inc., Fort Wayne, Ind.) and $0.1 \mathrm{ml}$ PTA-deficient plasma. $0.1 \mathrm{ml}$ of $0.025 \mathrm{M} \mathrm{CaCl}_{2}$ was immediately added and the clotting time was measured by tilting a tube at a constant rhythm (30 times/min), using a metronome as a pacer. The results were expressed as the 
clotting time and as the percentage of the activated PTA activity relative to that of the sample with the greatest activity. All purified clotting factors were diluted in $0.1 \%$ bovine serum albumin (BSA, crystallized, Pentex, Miles Laboratories, Kankakee, Ill.) and prewarmed at $37^{\circ} \mathrm{C}$ for $2 \mathrm{~min}$ before they were mixed together in the above system. The BSA used in these experiments was free of any known clotting factor activity and inhibitors of activated PTA. Other modifications used are described in the legends to tables and figures. The activation of PTA by HF-fragments was studied in the same way except HF-fragments $(27 \mu \mathrm{g} / \mathrm{ml})$ were used instead of $\mathrm{HF}$.

The possibility that HF may be fragmented in a mixture of HF, PTA, HMW-kininogen, and ellagic acid was studied as follows. $0.04 \mathrm{ml}{ }^{125} \mathrm{I}-\mathrm{HF}(0.4 \mathrm{U} / \mathrm{ml}, \cong 25,000 \mathrm{cpm})$, prepared as described (24), was incubated with $0.01 \mathrm{ml}$ partially purified PTA $(0.2 \mathrm{U} / \mathrm{ml})$ or highly purified PTA $(0.5$ $\mathrm{U} / \mathrm{ml}), 0.005 \mathrm{ml} \mathrm{HMW}$-kininogen $(1 \mathrm{U} / \mathrm{ml})$ and $0.02 \mathrm{ml}$ ellagic acid $(0.1 \mathrm{mM})$ or barbital-saline buffer in a $10 \times 95-\mathrm{mm}$ polystyrene tube at $37^{\circ} \mathrm{C}$. At $0,10,20$, and $30 \mathrm{~min}, 0.1 \mathrm{ml}$ $4 \%$ SDS and $1 \% \beta$-mercaptoethanol was added to the tube, and the tube was boiled for $3 \mathrm{~min}$. The mixture was subjected to SDS-gel electrophoresis. The gel was cut into 2-mm segments, and the radioactivity of each segment was counted on a gamma counter (Nuclear-Chicago, model 1085, Searle Analytic Inc., Des Plaines, Ill.).

\section{RESULTS}

The effect of HMW-kininogen upon the impaired surface-mediated plasma reactions of various plasmas. Plasmas from individuals with Hageman trait, Fletcher trait, and Fitzgerald trait are known to demonstrate impaired surface-mediated reactions such as blood coagulation, fibrinolysis, kinin generation, and augmentation of Factor VII activity (1-9). Addition of HMW-kininogen specifically corrected all of impaired surface-mediated plasma reactions of Fitzgerald trait plasma, but not those of Hageman trait or Fletcher trait plasma.

The effect of treatment of HMW-kininogen with plasma kallikrein or trypsin. When HMW-kininogen was incubated with trypsin, kinin activity was progressively generated with time, reaching a maximum

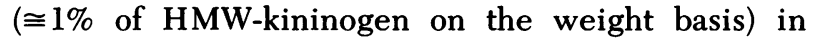
$10 \mathrm{~min}$. The clot-promoting activity of HMW-kininogen, as tested with Fitzgerald trait plasma, rapidly decreased during this period (Fig. 2). After $10 \mathrm{~min}$, when all kinin activity was released, only $1 \%$ of the original clotting activity remained. A mixture of equal amounts of unincubated aliquots and aliquots incubated for 30 min contained $\cong 50 \%$ of the original clot-promoting activity of unincubated aliquots, as though no inhibitor of clotting generated during incubation. Upon analytical disc gel electrophoresis, the original two bands disappeared, and a single band with faster mobility appeared as incubation proceeded. In contrast, when HMW-kininogen was incubated with plasma kallikrein, there was no loss of the clot-promoting activity even after kinin generation was apparently complete (Fig. 3), and its capacity to

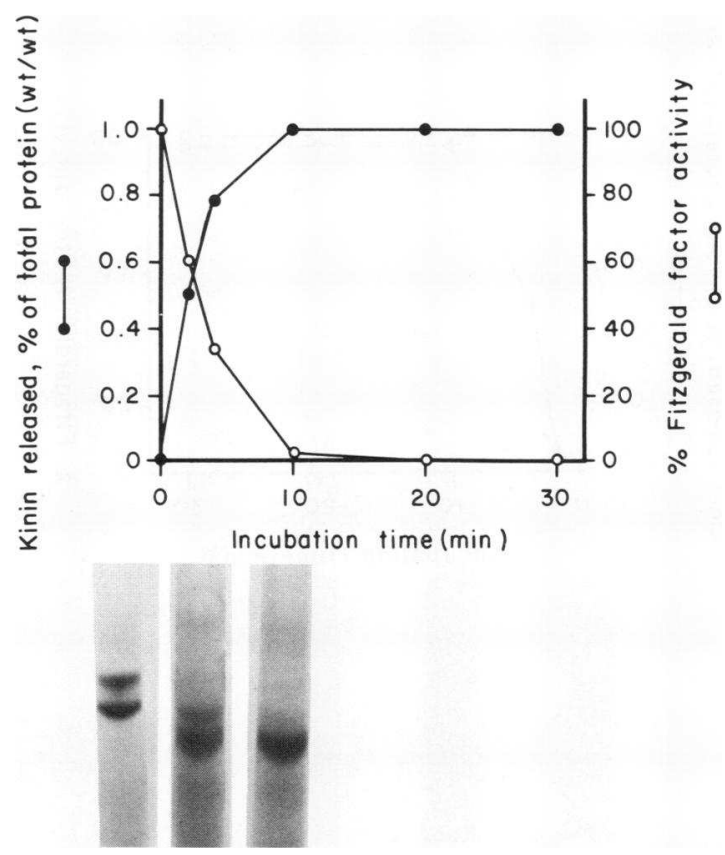

FIGURE 2 The effect of trypsin upon HMW-kininogen. $1 \mathrm{ml}$ HMW-kininogen $(2 \mathrm{U} / \mathrm{ml}, 0.115 \mathrm{mg} / \mathrm{ml})$ was incubated with $0.08 \mathrm{ml}$ trypsin $(0.1 \mathrm{mg} / \mathrm{ml})$ in a $12 \times 75-\mathrm{mm}$ polystyrene tube at $37^{\circ} \mathrm{C}$. At timed intervals, $0.16-\mathrm{ml}$ aliquots were transferred into $10 \times 75-\mathrm{mm}$ polystyrene tubes containing $0.04 \mathrm{ml}$ soybean trypsin inhibitor $(0.1 \mathrm{mg} / \mathrm{ml})$ and 0.02 $\mathrm{ml} 0.01 \mathrm{M} o$-phenanthroline. A $0.07-\mathrm{ml}$ aliquot was subjected to analytical disc gel electrophoresis, and the rest of the aliquot was used to measure kinin activity and HMW-kininogen clotting activity. The patterns of disc-gel electrophoresis at 0,2 , and $10 \mathrm{~min}$ are shown from left to right.

correct the fibrinolytic defect of Fitzgerald trait plasma was retained. The pattern of disc gel electrophoresis showed that the mobility of the faster-moving band slowed slightly and that two bands became closer to each other.

The role of HMW-kininogen in the activation of PTA by HF and ellagic acid. When highly purified PTA was incubated with $\mathrm{HF}$, plasma prekallikrein, HMW-kininogen, and ellagic acid, clot-promoting activity generated progressively as incubation proceeded (Table I). Similar results were obtained when a preparation of partially purified PTA was used. When kaolin (final concentration $0.06 \mathrm{mg} / \mathrm{ml}$ ) was used instead of ellagic acid, the generation of clot-promoting activity occurred very rapidly and it was difficult to follow the time-course of the reaction. Therefore, ellagic acid was used routinely in the following experiments. When either HF, PTA, HMW-kininogen, or ellagic acid was deleted from the mixture, the clotting time did not shorten. In contrast, the presence or absence of prekallikrein did not influence this system. The preparations of HF, PTA, and HMWkininogen were not contaminated with prekallikrein as 


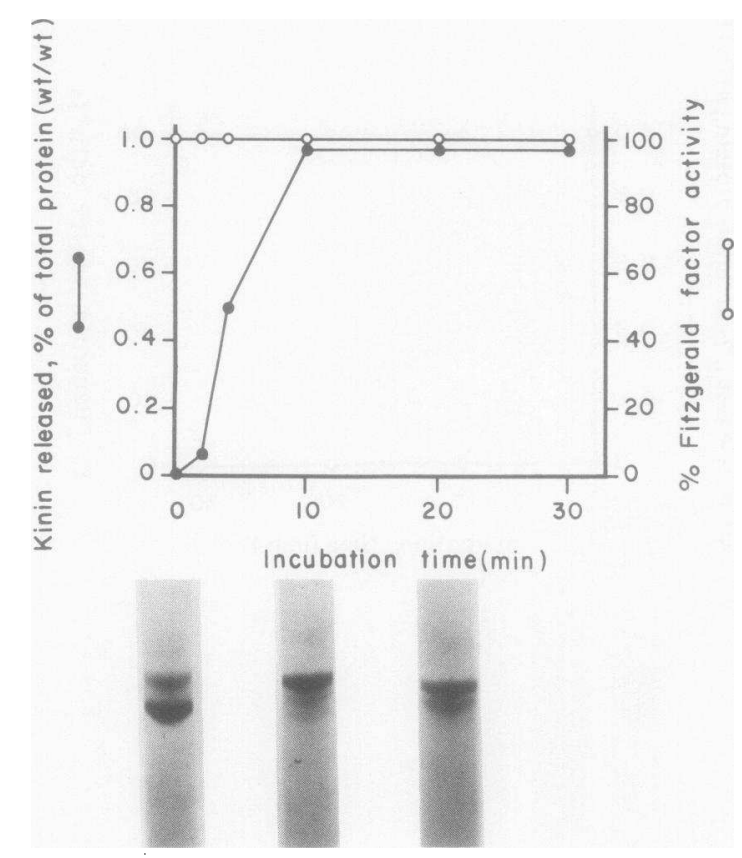

Figure 3 The effect of plasma kallikrein upon HMWkininogen. $1 \mathrm{ml}$ HMW-kininogen $(2 \mathrm{U} / \mathrm{ml}, 0.115 \mathrm{mg} / \mathrm{ml})$ was incubated with $0.08 \mathrm{ml}$ plasma kallikrein $(0.17 \mathrm{mg} / \mathrm{ml})$ in a $12 \times 75-\mathrm{mm}$ polystyrene tube at $37^{\circ} \mathrm{C}$. At time intervals, $0.16-\mathrm{ml}$ aliquots were transferred into $10 \times 75-\mathrm{mm}$ polystyrene tubes containing $0.04 \mathrm{ml}$ soybean trypsin inhibitor $(0.1 \mathrm{mg} / \mathrm{ml})$ and $0.02 \mathrm{ml} 0.01 \mathrm{M} \mathrm{o}$-phenanthroline. $0.07-\mathrm{ml}$ aliquots were subjected to analytical disc gel electrophoresis, and the rest of the aliquots were used to measure kinin activity and HMW-kininogen clotting activity. The patterns of disc gel electrophoresis at 0,2 , and $10 \mathrm{~min}$ are shown from left to right.

TABLE I

Activation of PTA by HF

\begin{tabular}{ccccc}
\hline & \multicolumn{4}{c}{ Clotting time } \\
\cline { 2 - 5 } Incubation mixture & $10 \mathrm{~s}$ & $5 \mathrm{~min}$ & $10 \mathrm{~min}$ & $15 \mathrm{~min}$ \\
\hline & & & & \\
HF + PTA + buffer & & & & \\
$\begin{array}{c}\text { + buffer + EA } \\
\text { HF + PTA + HMW-K } \\
+ \text { buffer + EA }\end{array}$ & 171.6 & 168.0 & 160.4 & 165.5 \\
$\begin{array}{c}\text { HF + PTA + HMW-K } \\
+ \text { prekallikrein + EA }\end{array}$ & 173.9 & 136.8 & 126.1 & 118.6 \\
$\begin{array}{c}\text { HF + PTA + buffer } \\
+ \text { prekallikrein + EA }\end{array}$ & 170.1 & 140.3 & 125.9 & 120.5 \\
\hline
\end{tabular}

In a $10 \times 75-\mathrm{mm}$ polystyrene tube the following reagents were incubated at $37^{\circ} \mathrm{C}: 0.075 \mathrm{ml}$ highly purified PTA $(0.05$ $\mathrm{U} / \mathrm{ml}), 0.025 \mathrm{ml} \mathrm{HF}(0.18 \mathrm{U} / \mathrm{ml}), 0.025 \mathrm{ml}$ prekallikrein $(0.1$ $\mathrm{U} / \mathrm{ml})$ or BSA, $0.025 \mathrm{ml} \mathrm{HMW-kininogen}(\mathrm{K})(0.2 \mathrm{U} / \mathrm{ml})$ or BSA, and $0.075 \mathrm{ml} 0.1 \mathrm{mM}$ ellagic acid (EA). At intervals, 0.05-ml aliquots were tested for activated PTA as described in Methods. The results were the arithmetic sum of the triplicate determinations. tested by a sensitive radioimmunoassay. $\mathrm{HF}$ at 16 $\mathrm{U} / \mathrm{ml}$, highly purified and partially purified PTA at $4 \mathrm{U} / \mathrm{ml}$, and $\mathrm{HMW}$-kininogen at $2 \mathrm{U} / \mathrm{ml}$ contained $<0.003 \mathrm{U} / \mathrm{ml}$ prekallikrein. In the following experiments, partially purified PTA was used. Evidence that activated PTA activity was generated in a mixture of HF, PTA, HMW-kininogen, and ellagic acid came from the following experiments. First, when aliquots of the mixture were tested on a substrate of Christmas factor (Factor IX)-deficient plasma, there was no shortening of the clotting time. Second, antibodies against HF, PTA, and HMW-kininogen all abolished the generation of clot-promoting activity in the incubation mixture when these were added before the addition of ellagic acid (Fig. 4A). None of the antibodies except anti-PTA, however, inactivated clot-promoting activity after HF, PTA, and HMW-kininogen were incubated with ellagic acid for $10 \mathrm{~min}$ (Fig. 4B). These experiments indicate that HMW-kininogen is absolutely required for the activation of PTA by $\mathrm{HF}$ and ellagic acid.

Preliminary incubation of HF and HMW-kininogen with ellagic acid before the addition of PTA did not

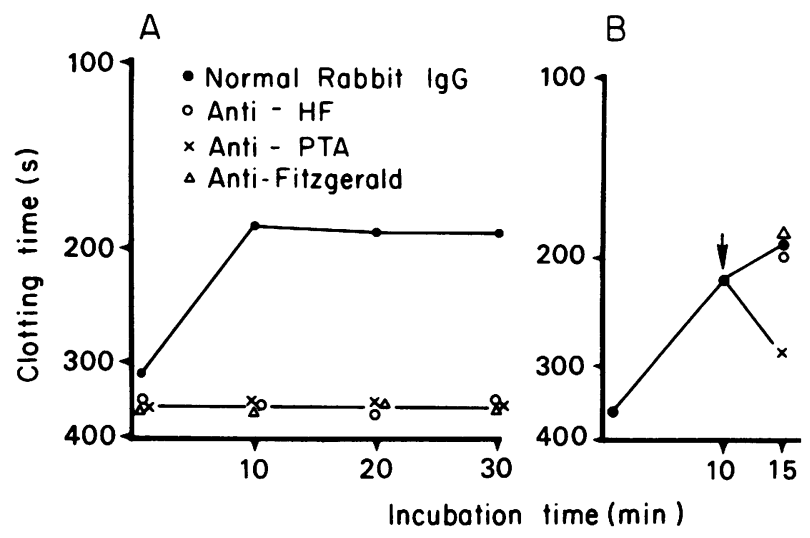

Figure 4 (A) The effect of antibodies against HF, PTA, and HMW-kiniogen upon the generation of clot-promoting activity. In a $10 \times 75-\mathrm{mm}$ polystyrene tube, $0.075 \mathrm{ml}$ PTA $(0.2$ $\mathrm{U} / \mathrm{ml})$ was incubated at $37^{\circ} \mathrm{C}$ with $0.025 \mathrm{ml} \mathrm{HF}(0.18 \mathrm{U} / \mathrm{ml})$, $0.025 \mathrm{ml} \mathrm{HMW}$-kininogen $(0.04 \mathrm{U} / \mathrm{ml})$, and $0.025 \mathrm{ml}$ antibodies against HF, PTA, or HMW-kininogen or normal rabbit IgG. After $5 \mathrm{~min}, 0.075 \mathrm{ml}$ ellagic acid $(0.1 \mathrm{mM})$ was then added to the mixture and the mixture was further incubated. At timed intervals, 0.05-ml aliquots were tested for activated PTA activity as described in Methods. (B) The effect of antibodies against HF, PTA, and HMW-kininogen upon generated clot-promoting activity. In a $10 \times 75-\mathrm{mm}$ polystyrene tube, $0.105 \mathrm{ml}$ PTA $(0.2 \mathrm{U} / \mathrm{ml})$ was incubated at $37^{\circ} \mathrm{C}$ with $0.035 \mathrm{ml} \mathrm{HF}(0.18 \mathrm{U} / \mathrm{ml}), 0.035 \mathrm{ml} \mathrm{HMW}$-kininogen $(0.04 \mathrm{U} / \mathrm{ml}), 0.035 \mathrm{ml} \mathrm{BSA}$, and $0.105 \mathrm{ml}$ ellagic acid $(0.1 \mathrm{mM})$. After $10 \mathrm{~min}$, the mixture was divided into $0.06-\mathrm{ml}$ aliquots and to each aliquot was added $0.012 \mathrm{ml}$ of antibodies against HF, PTA, or HMW-kininogen or normal rabbit IgG. The mixtures were incubated at $37^{\circ} \mathrm{C}$ for $5 \mathrm{~min}$, and $0.06-\mathrm{ml}$ aliquots were tested for activated PTA activity as described in Methods. 
appreciably change the rate or degree of generation of activated PTA activity. HMW-kininogen retained its clot-promoting activity in a purified system after all kinin activity was removed by treatment with plasma kallikrein.

The way in which PTA was activated was investigated by testing the effect of varying concentration of either HF, PTA, HMW-kininogen, or ellagic acid on the evolution of activated-PTA activity. Since each protein was diluted in this experiment, the stability of the clot-promoting activity of each protein was first examined. The activities of $\mathrm{HF}$, PTA, and HMWkininogen were stable at any concentration used in the following experiments as tested on the respective substrate plasmas after incubation for $30 \mathrm{~min}$ at $37^{\circ} \mathrm{C}$.

When the concentration of PTA was varied over a ninefold range and the concentration of other reagents was kept constant, the yield of activated PTA activity varied in proportion to the concentration of PTA (Fig. 5). After $10 \mathrm{~min}$, when the generation of activated PTA activity reached a plateau, further additions of each reagent were made to the mixture. Only the addition of PTA resulted in a further generation of clot-promoting activity (Fig. 6). When the concentration of HMW-kininogen was varied over a 16fold range, and the concentration of other reagents was kept constant, the yield of activated PTA activity varied in proportion to the concentration of HMW-kininogen (Fig. 7). After $20 \mathrm{~min}$, when activated PTA activity reached its maximum, each reagent was added to the mixture. Only the addition of HMWkininogen resulted in the further generation of clotpromoting activity under these conditions (Fig. 8). When the concentration of HF was changed over an 18 -fold range, and those of other reagents were kept

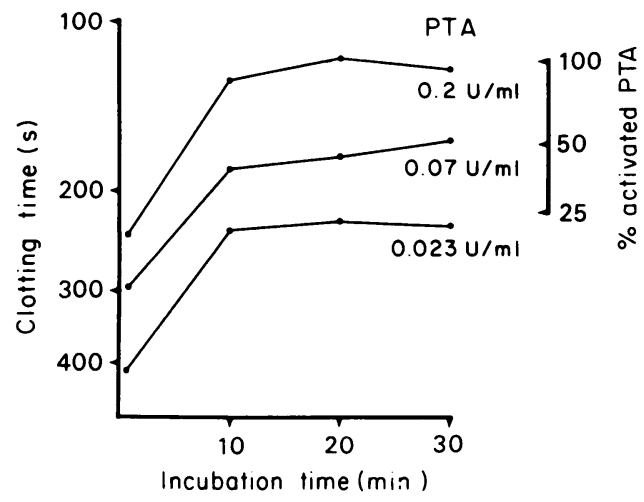

FIGURE 5 The effect of varying the concentration of PTA upon PTA activation. In a $10 \times 75-\mathrm{mm}$ polystyrene tube, 0.075 $\mathrm{ml}$ PTA $(0.2,0.07$, or $0.023 \mathrm{U} / \mathrm{ml})$ was incubated at $37^{\circ} \mathrm{C}$ with $0.025 \mathrm{ml} \mathrm{HF}(1.8 \mathrm{U} / \mathrm{ml}), 0.025 \mathrm{ml} \mathrm{HMW}$-kininogen $(1 \mathrm{U} / \mathrm{ml})$, $0.025 \mathrm{ml} \mathrm{BSA}$, and $0.075 \mathrm{ml}$ ellagic acid $(0.1 \mathrm{mM})$. At timed intervals, $0.05-\mathrm{ml}$ portions of this mixture were tested for activated PTA activity as described in Methods.

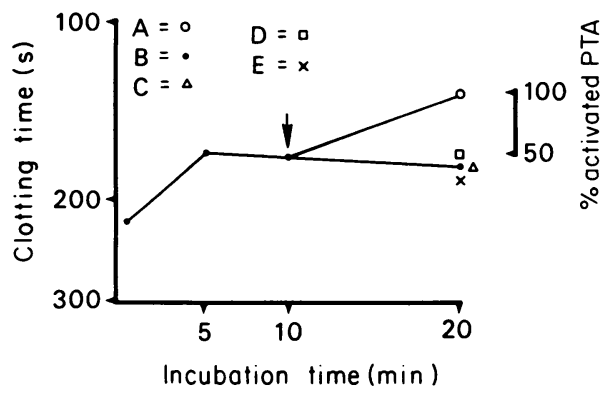

FIGURE 6 The effect of further addition of HF, HMWkininogen, PTA, and ellagic acid upon PTA activation. In a $12 \times 75-\mathrm{mm}$ polystyrene tube, $0.225 \mathrm{ml}$ PTA $(0.2 \mathrm{U} / \mathrm{ml})$ was incubated at $37^{\circ} \mathrm{C}$ with $0.075 \mathrm{ml} \mathrm{HF}(1.8 \mathrm{U} / \mathrm{ml}), 0.075 \mathrm{ml}$ HMW-kininogen $(1 \mathrm{U} / \mathrm{ml}), 0.075 \mathrm{ml} \mathrm{BSA}$, and $0.225 \mathrm{ml}$ ellagic acid $(0.1 \mathrm{mM})$. After incubation for $10 \mathrm{~s}$ or for 5 or $10 \mathrm{~min}$, 0.05- $\mathrm{ml}$ aliquots were tested for activated PTA activity. At 10 min, as indicated by an arrow, the reaction mixture was divided into $0.1-\mathrm{ml}$ aliquots, and to each $0.1-\mathrm{ml}$ aliquot was added $0.025 \mathrm{ml}$ of either (A) PTA $(0.2 \mathrm{U} / \mathrm{ml})$, (B) HF (1.8 $\mathrm{U} / \mathrm{ml}),(\mathrm{C}) \mathrm{HMW}$-kininogen $(1 \mathrm{U} / \mathrm{ml})$, (D) ellagic acid $(0.1 \mathrm{mM})$, or (E) BSA. The mixtures were further incubated for $10 \mathrm{~min}$, and $0.05-\mathrm{ml}$ aliquots were tested as above.

constant, the yield of activated PTA activity varied in relation to the concentration of HF (Fig. 9). When the generation of activated PTA activity reached its maximum under these conditions, only the addition of $\mathrm{HF}$ induced more clot-promoting activity (Fig. 10). Changing the concentration of ellagic acid from 0.1 to $0.001 \mathrm{mM}$ did not significantly alter the generation of activated-PTA activity. When the concentration was lower than $0.001 \mathrm{mM}$, the yield of activated PTA was proportionately reduced. Thus, in these experiments the yield of activated PTA depended not only upon the concentration of PTA, but also

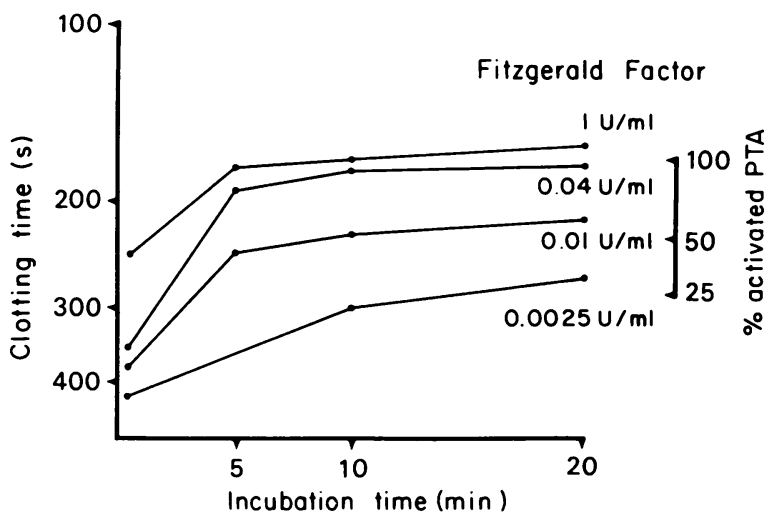

FIgURE 7 The effect of varying concentration of HMWkininogen upon PTA activation. In a $10 \times 75-\mathrm{mm}$ polystyrene tube, $0.075 \mathrm{ml}$ PTA $(0.2 \mathrm{U} / \mathrm{ml})$ was incubated at $37^{\circ} \mathrm{C}$ with $0.025 \mathrm{ml} \mathrm{HF}(1.8 \mathrm{U} / \mathrm{ml}), 0.025 \mathrm{ml} \mathrm{HMW}$-kininogen $(1,0.04$, 0.01 , or $0.0025 \mathrm{U} / \mathrm{ml}), 0.025 \mathrm{ml} \mathrm{BSA}$, and $0.075 \mathrm{ml}$ ellagic acid $(0.1 \mathrm{mM})$. At timed intervals, $0.05-\mathrm{ml}$ aliquots were tested for activated PTA activity as described in Methods. 


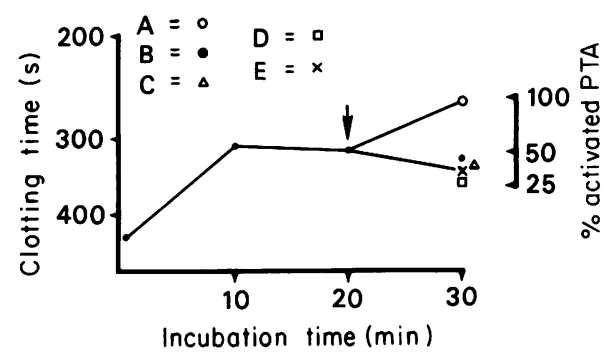

FIGURE 8 The effect of further addition of HF, HMWkininogen, PTA, and ellagic acid upon PTA activation. In a $12 \times 75-\mathrm{mm}$ polystyrene tube, $0.225 \mathrm{ml}$ PTA $(0.2 \mathrm{U} / \mathrm{ml})$ was incubated at $37^{\circ} \mathrm{C}$ with $0.075 \mathrm{ml} \mathrm{HF}(1.8 \mathrm{U} / \mathrm{ml}), 0.075 \mathrm{ml}$ HMW-kininogen $(0.0025 \mathrm{U} / \mathrm{ml}), 0.075 \mathrm{ml} \mathrm{BSA}$, and $0.225 \mathrm{ml}$ ellagic acid $(0.1 \mathrm{mM})$. At $10 \mathrm{~s}$ and at 10 and $20 \mathrm{~min}, 0.05-\mathrm{ml}$ aliquots were tested for activated PTA activity. At $20 \mathrm{~min}$, as indicated by the arrow, the reaction mixture was divided into $0.1-\mathrm{ml}$ aliquots and to each $0.1-\mathrm{ml}$ aliquot was added 0.025 $\mathrm{ml}$ of either (A) HMW-kininogen $(0.04 \mathrm{U} / \mathrm{ml})$, (B) HF (1.8 $\mathrm{U} / \mathrm{ml}),(C)$ PTA $(0.2 \mathrm{U} / \mathrm{ml})$, (D) ellagic acid $(0.1 \mathrm{mM})$, or $(\mathrm{E})$ $\mathrm{BSA}$. The mixtures were incubated for an additional $10 \mathrm{~min}$, and the $0.05-\mathrm{ml}$ aliquots were then tested as above.

upon the concentrations of HF, HMW-kininogen, and ellagic acid.

The role of HMW-kininogen in the activation of PTA by HF-fragments. HF-fragments (approximate mol wt 30,000) are derived from HF (mol wt 80,000) by the action of proteolytic enzymes such as plasmin, kallikrein, or trypsin (25-27). These fragments are very potent activators of prekallikrein, but only weakly clot-promoting (28). The activation of PTA by HFfragments was studied in two different ways. First, the effect of HF-fragments upon the partial thromboplastin time (PTT) of various plasmas was studied

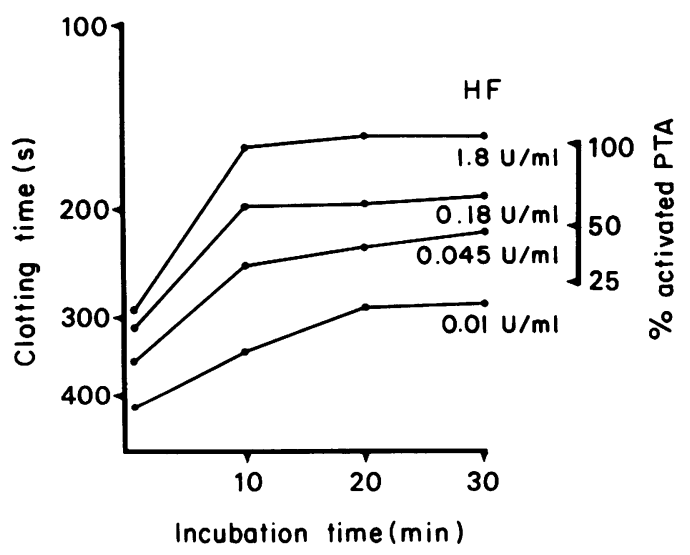

FIgURE 9 The effect of varying the concentration of $\mathbf{H F}$ upon PTA activation. In a $10 \times 75-\mathrm{mm}$ polystyrene tube, $0.075 \mathrm{ml}$ PTA $(0.2 \mathrm{U} / \mathrm{ml})$ was incubated at $37^{\circ} \mathrm{C}$ with 0.025 $\mathrm{ml} \mathrm{HF}(1.8,0.18,0.045$, or $0.01 \mathrm{U} / \mathrm{ml}), 0.025 \mathrm{ml}$ HMWkininogen $(1 \mathrm{U} / \mathrm{ml}), 0.025 \mathrm{ml} \mathrm{BSA}$, and $0.075 \mathrm{ml}$ ellagic acid $(0.1 \mathrm{mM})$. At timed intervals, $0.05-\mathrm{ml}$ aliquots were tested for activated PTA activity as described in Methods.

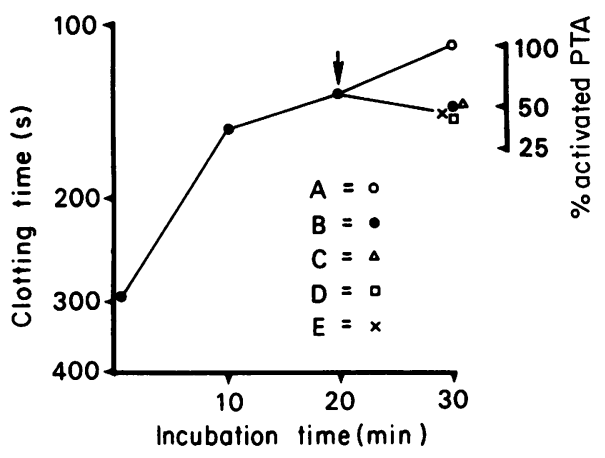

FIGURE 10 The effect of further addition of HF, HMWkininogen, PTA, and ellagic acid upon PTA activation. In a $12 \times 75$-mm polystyrene tube, $0.225 \mathrm{ml} \mathrm{PTA}(0.2 \mathrm{U} / \mathrm{ml})$ was incubated at $37^{\circ} \mathrm{C}$ with $0.075 \mathrm{ml} \mathrm{HF}(0.045 \mathrm{U} / \mathrm{ml}), 0.075 \mathrm{ml}$ HMW-kininogen $(0.2 \mathrm{U} / \mathrm{ml}), 0.075 \mathrm{ml} \mathrm{BSA}$, and $0.225 \mathrm{ml}$ ellagic acid $(0.1 \mathrm{mM})$. At 10 -s and at 10 - and 20 -min incubations, 0.05-ml aliquots were tested for activated PTA activity upon PTA-deficient plasma. At $20 \mathrm{~min}$, as indicated by the arrow, the reaction mixture was divided into $0.1-\mathrm{ml}$ aliquots, and to each $0.1 \mathrm{ml}$ aliquot was added $0.025 \mathrm{ml}$ of either (A) HF (0.8 U/ml), (B) HMW-kininogen $(0.2 \mathrm{U} / \mathrm{ml}),(\mathrm{C})$. PTA $(0.2 \mathrm{U} / \mathrm{ml})$, (D) ellagic acid $(0.1 \mathrm{mM})$, or (E) BSA. The mixtures were further incubated for $10 \mathrm{~min}$, and $0.05-\mathrm{ml}$ aliquots were tested as above.

in comparison to HF-ellagic acid (Table II). The addition of HF-ellagic acid shortened the PTT of Hageman trait and Fletcher trait plasmas from $>400 \mathrm{~s}$ to 186.0 and $134.0 \mathrm{~s}$, respectively. But it did not significantly shorten the PTT of Fitzgerald trait plasma, consistent with our earlier studies using HF-kaolin (12). In contrast, the addition of HF-fragments shortened the prolonged PTT of Hageman trait and Fitzgerald trait plasmas to 198.0 and 175.5 s, respectively; HF-fragments corrected the PTT of both Hageman trait and Fitzgerald trait plasmas to the same degree. The concentration of $\mathrm{HF}$-fragments required to give the same degree of correction in Hageman trait was $\cong 100 \times$ as great as that of $\mathrm{HF}$ on a weight basis. The coagulant activity of HF-fragments upon Fitzgerald trait plasma was unaffected when this plasma was reconstituted with HMW-kininogen. In contrast, the effect of HF-ellagic acid upon the reconstituted plasma was dramatic (Table II, Exp B). These experiments suggest that HF-fragments can activate PTA in the absence of HMW-kininogen. This possibility was studied in a purified system. When PTA was incubated with HF-fragments, plasma prekallikrein, HMW-kininogen, and ellagic acid, and aliquots of this mixture were tested upon a substrate of PTA-deficient plasma, the clotting time progressively shortened with time (Table III). The generation of activated PTA activity was unaffected when HMW-kininogen, plasma prekallikrein, and ellagic acid were removed from the mixture. But no activation of PTA occurred without the addition of HF-fragments. These experi- 
TABLE II

Effect of Addition of HF Fragments upon the PTT of Various Plasmas

\begin{tabular}{llccc}
\hline & & \multicolumn{3}{c}{ PTT } \\
\cline { 3 - 5 } & \multicolumn{1}{c}{ Test Plasmas } & $\begin{array}{c}\text { HF-Frag- } \\
\text { ments }\end{array}$ & $\begin{array}{c}\text { HF-El- } \\
\text { lagic acid }\end{array}$ & Buffer \\
\hline & & & $s$ & \\
Exp. A & Hageman trait & 198.0 & 186.0 & $>400$ \\
& Fitzgerald trait & 175.5 & $>400$ & $>400$ \\
& Fletcher trait & 157.9 & 134.0 & $>400$ \\
& PTA deficiency & $>400$ & $>400$ & $>400$ \\
Exp. B & Hageman trait + buffer & 280.8 & 264.4 & $>600$ \\
& Fitzgerald trait + buffer & 235.3 & $>600$ & $>600$ \\
& Fitzgerald trait + HMW-K & 230.4 & 256.2 & $>600$ \\
\hline
\end{tabular}

Exp. A: in a $10 \times 75-\mathrm{mm}$ polystyrene tube, $0.1 \mathrm{ml}$ test plasma was incubated at $37^{\circ} \mathrm{C}$ for $1 \mathrm{~min}$ with $0.1 \mathrm{ml}$ Centrolex $\mathrm{O}$, and $0.15 \mathrm{ml}$ HF-fragments (18 $\mu \mathrm{g} / \mathrm{ml}$ ) or HF-ellagic acid mixture (HF- $0.2 \mu \mathrm{g} / \mathrm{ml}$, ellagic acid $0.03 \mathrm{mM}$ ). $0.1 \mathrm{ml} 0.025 \mathrm{M} \mathrm{CaCl}_{2}$ was then added to the mixture and the clotting time recorded at $37^{\circ} \mathrm{C}$.

Exp. B: in a $10 \times 75-\mathrm{mm}$ polystyrene tube, a mixture of $0.8 \mathrm{ml}$ test plasma and $0.2 \mathrm{ml} \mathrm{HMW-kininogen}(\mathrm{K})(5 \mathrm{U} / \mathrm{ml})$ or barbital-saline buffer was incubated at $37^{\circ} \mathrm{C}$ for $1 \mathrm{~min}$ with $0.1 \mathrm{ml}$ Centrolex $\mathrm{O}$ and $0.15 \mathrm{ml} \mathrm{HF}$-fragments $(10 \mu \mathrm{g} / \mathrm{ml})$ or HF-ellagic acid mixture (HF $0.1 \mu \mathrm{g} / \mathrm{ml}$, ellagic acid $0.03 \mathrm{mM}$ ). The tube was then recalcified and tested as above. The results were the mean of the duplicate determinations.

ments suggest that $\mathrm{HF}$-fragments directly activate PTA in the absence of ellagic acid and HMWkininogen, and that HMW-kininogen does not enhance the action of HF-fragments.

Evidence that no fragmentation of HF occurs in a mixture of HF, PTA, HMW-kininogen, and ellagic acid. Since HF-fragments activated PTA without the participation of ellagic acid or HMW-kininogen, we tested the possibility that HF-fragments may be generated in a mixture of HF, PTA, HMW-kininogen, and ellagic acid. When ${ }^{125} \mathrm{I}-\mathrm{HF}$ was incubated with HMW-kininogen, PTA, and ellagic acid, and aliquots were subjected to SDS-gel electrophoresis after reduction with $\beta$-mercaptoethanol, no significant radioactivity was found in the lower molecular weight region.

\section{DISCUSSION}

In 1974, we described a new asymptomatic disorder (Fitzgerald trait) of blood coagulation associated with impaired surface-mediated fibrinolysis, kinin generation, and enhancement of vascular permeability by diluted plasma $(5,6)$. Subsequently, five additional unrelated individuals have been described who have the same clotting defect as Fitzgerald trait $(10,13$, 14, 29). ${ }^{2}$ Wuepper et al. (10) first identified an agent

\footnotetext{
${ }^{2}$ Fenning, R., and A. Cox. 1976. Personal communication.
}

deficient in the plasma of their patient (Flaujeac trait) as high molecular weight (HMW)-kininogen. Almost simultaneously, the same finding was reported in other individuals with the same clotting defect (12-14). Although individuals with HMW-kininogen deficiencies (11-14) have the same clotting defect, they exhibited different defects in the kinin-forming system. The plasma concentrations of prekallikrein and low molecular weight kininogen were quite variable in different cases. Mr. Fitzgerald's plasma is functionally deficient in HMW-kininogen (12), whereas plasmas of other patients $(11,13,14)$ are more or less deficient in both low molecular weight and HMW-kininogen. Plasma prekallikrein activity in some patients $(12-14)$ is low $(10-45 \%$ of normal plasma), and in others (11) is normal. Therefore, each case must be studied carefully to elucidate the interactions of agents involving blood coagulation and kinin formation.

In the present study, HMW-kininogen was highly purified from normal human plasma (1,200 times purified over plasma) by monitoring its clot-promoting activity, using Fitzgerald trait plasma as a substrate. the HMW-kininogen clotting assay is an easy and quick way to localize HMW-kininogen during the fractionation of plasma compared to the time-consuming kininogen assay. Our earlier preparations of HMW-kininogen monitored by this assay released, however, only small amounts of kinin activity upon kallikrein or trypsin treatment. This was probably

TABLE III

Activation of PTA by HF-Fragments

\begin{tabular}{ccccc}
\hline & \multicolumn{4}{c}{ Clotting time } \\
\cline { 2 - 5 }$\quad$ Incubation mixture & $10 \mathrm{~s}$ & $10 \mathrm{~min}$ & $20 \mathrm{~min}$ & $30 \mathrm{~min}$ \\
\hline & & & & \\
& & & & \\
$\begin{array}{c}\text { HFf + PTA + prekalli- } \\
\text { krein + HMW-K + EA }\end{array}$ & 252.9 & 219.8 & 199.1 & 190.8 \\
$\begin{array}{c}\text { HFf + PTA + BSA } \\
\quad+\text { HMW-K + EA }\end{array}$ & 241.1 & 224.2 & 187.9 & 176.8 \\
$\begin{array}{c}\text { HFf + PTA + BSA } \\
+ \text { BSA + EA }\end{array}$ & 257.1 & 201.3 & 190.5 & 178.3 \\
$\begin{array}{c}\text { HFf + PTA + BSA } \\
\quad+\text { BSA + BS }\end{array}$ & 259.6 & 215.7 & 195.8 & 182.0 \\
$\begin{array}{c}\text { BSA + PTA + prekalli- } \\
\text { krein + HMW-K + EA }\end{array}$ & 258.0 & 271.3 & 252.3 & 268.7 \\
\hline
\end{tabular}

In a $10 \times 75$-mm polystyrene tube, the following prewarmed reagents were incubated at $37^{\circ} \mathrm{C}: 0.075 \mathrm{ml}$ PTA $(0.2 \mathrm{U} / \mathrm{ml})$, $0.025 \mathrm{ml} \mathrm{HMW}$-kininogen $(\mathrm{K})(0.04 \mathrm{U} / \mathrm{ml}), 0.025 \mathrm{ml}$ prekallikrein $(0.2 \mathrm{U} / \mathrm{ml}), 0.075 \mathrm{ml} \mathrm{HF}$-fragments (HFf) $(27 \mu \mathrm{g} / \mathrm{ml})$ and $0.025 \mathrm{ml}$ ellagic acid (EA) $(0.1 \mathrm{mM})$. Barbital-saline buffer (BS) and BSA in BS were used as controls in the appropriate places. At intervals, $0.05-\mathrm{ml}$ aliquots were tested for activated PTA activity as described in Methods. 
due to the spontaneous activation of kininogenase and loss of kinins from kininogen. The addition of benzamidine at ammonium sulfate fractionation steps and of diisopropylfluorophosphate obviated this problem $(15,16)$. Peaks of clotting activity and of kininogen could not be separated during purification. In all fractionation steps, only one peak of clotting activity was detected, in contrast to Williams trait plasma (14) which had more than one peak of the corrective activity. Our preparation of HMW-kininogen specifically repaired impaired surface-mediated plasma reactions of Fitzgerald trait plasma. It displayed a single band upon SDS-gel electrophoresis (mol wt: 120,000) and two bands upon polyacrylamide gel electrophoresis. $1 \mathrm{mg}$ of this protein released $10 \mu \mathrm{g}$ of bradykinin-like material upon treatment with plasma kallikrein or trypsin. These properties of our HMWkininogen are consistent with those of a previous report (15). Highly purified bovine HMW-kininogen also displayed two bands on acrylamide gel electrophoresis (subspecies a and b) (16), both of which have recently been shown to be equally efficient in correcting the defect in Flaujeac trait plasma (30).

Removal of kinin from HMW-kininogen by action of trypsin resulted in loss of its clot-promoting activity. In contrast, HMW-kininogen retained its ability to repair the impaired clotting and fibrinolysis of Fitzgerald trait plasma when comparable amounts of kinin activity were removed by plasma kallikrein. Furthermore, HMW-kininogen, from which all kinin activities were removed, functioned equally well in the activation of PTA in a purified system. These findings are in agreement with data reported by Colman et al. (14), but are in contrast with a recent report that treatment of HMW-kininogen with kallikrein decreases its potentiating effect in the activation of prekallikrein by activated HF (31). Recently, Japanese researchers demonstrated that a potent inhibitor of blood coagulation (a histidine-rich peptide) was released from bovine HMW-kininogen by plasma kallikrein (32). Although no detailed structure of human HMW-kininogen comparable to that of bovine protein has yet been reported, no such inhibitory activity was identified in the present study.

Normal human plasma clots rapidly upon contact with a foreign surface such as glass through a sequence of reactions designated as the intrinsic pathway of thrombin formation. It was originally thought that activated HF (Factor XIIa) directly activates PTA $(33,34)$. Studies on Fletcher trait plasma (7-9) suggest that plasma prekallikrein may be needed for optimal activation of PTA in plasma. Schiffman and Lee (35), however, could not activate PTA in a mixture of kaolin, HF, prekallikrein, and PTA, suggesting a requirement for an additional factor (contact activation co-factor), although certain forms of activated HF (HF-fragments) have been shown to activate PTA directly $(36,37)$. Earlier, we showed that Fitzgerald factor, i.e., HMW-kininogen, participated in the early steps of the intrinsic pathway before the activation of PTA (6). Subsequently, the identity of Fitzgerald factor and contact activation co-factor was reported (38).

In the present study, the role of HMW-kininogen as well as $\mathrm{HF}$, PTA, and plasma prekallikrein in the activation of PTA was studied in a purified system. Immunologic studies (Fig. 4 A, B) identified the clot-promoting agent generated as activated PTA. It was possible to follow the time-course of activation of PTA by using ellagic acid as an activator and appropriate dilutions of purified clotting factors. In all experiments, the reaction was triggered by adding ellagic acid to a mixture containing purified proteins to simulate the activation of PTA in whole plasma. It appeared that HMW-kininogen is absolutely necessary for the activation of PTA by HF and ellagic acid. In contrast to recent reports $(39,40)$, we could not show an additional effect of plasma prekallikrein. Our preparations of PTA and prekallikrein had much higher specific activity compared to those in an earlier report (40). One possible explanation is that our HF preparations had already been modified during purification, so that they no longer needed prekallikrein for their effect.

The role of each component in the activation of PTA was further studied by changing the concentration of each reagent. Because the system under study is complex, we could not measure the initial velocity of the reaction. Therefore, we measured the yield of activated PTA and tested the effect of further additions of each component after the reaction had reached a plateau. Kinetic studies showed that the yield of activated PTA was related to the amounts of PTA, $\mathrm{HF}$, and HMW-kininogen in the mixtures. Our results are consistent with the hypothesis that neither $\mathrm{HF}$, PTA, nor HMW-kininogen alone can act catalytically, but they may form a complex in the presence of ellagic acid. Whether activated PTA remains attached to a complex is not clear. As far as HMWkininogen is concerned, this is consistent with a previous report (41) that the amount of activated PTA was proportional to the amount of contact activation co-factor (HMW-kininogen) present. Griffin and Cochrane (40) have also recently reported that optimal activation of PTA occurred when HF and HMWkininogen were added in 1:1 proportion by weight. The molecular mechanisms of the actions of HMWkininogen are not yet clear. HMW-kininogen has no recognized enzymatic activities, and it probably provides steric orientation of HF necessary for its optimal action.

In contrast to $\mathrm{HF}, \mathrm{HF}$-fragments (mol wt: 30,000 ) did 
not require $\mathrm{HMW}$-kininogen to activate PTA, as examined in experiments with whole plasma (Table II) and in a purified system (Table III). The reconstitution of HMW-kininogen-deficient plasma with HMW-kininogen did not enhance the action of HFfragments in the clotting system. The possibility that fragmentation of $\mathrm{HF}$ had taken place in a mixture of HF, PTA, HMW-kininogen, and ellagic acid is unlikely. Even if it occurs, the amount of HF-fragments derived from $\mathrm{HF}$ in the mixture would be too little to be clot-promoting.

Thus, it appears that there were two distinct ways to activate PTA in our studies, by HF-HMWkininogen-ellagic acid or by $\mathrm{HF}$-fragments. Which pathway is the major one in whole plasma remains to be determined. In this regard, it is interesting to note that ${ }^{125} \mathrm{I}-\mathrm{HF}$ was cleaved very slowly into 28,000 mol wt fragments in prekallikrein or HMWkininogen-deficient plasmas exposed to glass (42). It is well known that the PTT of prekallikrein-deficient plasma, but not of HMW-deficient plasma, becomes normal after prolonged exposure to surfaces $(4,12)$, activation of PTA in prekallikrein-deficient plasma may not be dependent upon the generation of HFfragments. Further work is needed to explain the data obtained in purified systems and to elucidate the mode of activation of PTA in whole blood.

\section{ACKNOWLEDGMENTS}

I wish to thank Dr. O. D. Ratnoff for his encouragement and support and Dr. K. Neet, Department of Biochemistry, Case Western Reserve University, for his helpful discussion of enzyme kinetics. Ms. Ellen Strecker provided invaluable technical help.

This work was supported in part by research grant $\mathrm{HL}$ 01661 from the National Heart and Lung Institute of the National Institutes of Health and in part by grants from the National American Heart Association and the Northeast Ohio Affiliate of the American Heart Association.

\section{REFERENCES}

1. Ratnoff, O. D., and J. M. Rosenblum. 1958. Role of Hageman factor in the initiation of clotting by glass: evidence that glass frees Hageman factor from inhibition. Am. J. Med. 25: 160-168.

2. Niewiarwoski, S., and O. Prou-Wartelle. 1959. Rôle du facteur contact (facteur Hageman) dans la fibrinolyse. Thromb. Diath. Haemorrh. 3: 593-603.

3. Margolis, J. 1958. Activation of plasma by contact with glass. Evidence for a common reaction which releases plasma kinin and initiates coagulation. J. Physiol. (Lond.). 144: 1-22.

4. Hathaway, W. E., L. P. Belhasen, and H. S. Hathaway. 1965. Evidence for a new plasma thromboplastin factor. I. Case report, coagulation studies, and physicochemical properties. Blood. 26: 521-532.

5. Waldmann, R., and J. Abraham. 1974. Fitzgerald factor: a heretofore unrecognized coagulation factor. Blood. 44: 934. (Abstr.)

6. Saito, H., O. D. Ratnoff, R. Waldmann, and J. Abraham.
1974. Impaired Hageman factor (factor XII)-mediated reactions in "Fitzgerald trait." Blood. 44: 934. (Abstr.)

7. Wuepper, K. D. 1972. Biochemistry and biology of components of the plasma kinin-forming system. In Inflammation: Mechanisms and Controls. I. H. Lepow and P. A. Ward, editors. Academic Press, Inc., New York. 93-117.

8. Saito, H., O. D. Ratnoff, and V. H. Donaldson. 1974. Defective activation of clotting, fibrinolysis, and permeability-enhancing systems in human Fletcher trait plasma. Circ. Res. 34: 641-651.

9. Weiss, A. S., J. I. Gallin, and A. P. Kaplan. 1974. Fletcher factor deficiency. A diminished rate of Hageman factor activation caused by absence of prekallikrein with abnormalities of coagulation, fibrinolysis, chemotactic activity and kinin generation. J. Clin. Invest. 53: $622-633$.

10. Wuepper, K. D., D. R. Miller, and M. J. Lacombe. 1975. Flaujeac trait: deficiency of kininogen in man. Fed. Proc. 34: 859. (Abstr.)

11. Wuepper, K. D., D. R. Miller, and M. J. Lacombe. 1975. Flaujeac trait. Deficiency of human plasma kininogen. J. Clin. Invest. 56: 1663-1672.

12. Saito, H., O. D. Ratnoff, R. Waldmann, and J. P. Abraham. 1975. Fitzgerald trait. Deficiency of a hitherto unrecognized agent, Fitzgerald factor, participating in surface-mediated reactions of clotting, fibrinolysis, and generation of kinins and PF/Dil. J. Clin. Invest. 55: 1082-1089.

13. Donaldson, V. H., H. I. Glueck, M. A. Miller, H. Z. Movat, and F. Habal. 1976. Kininogen deficiency in Fitzgerald trait: role of high molecular weight kininogen in clotting and fibrinolysis. J. Lab. Clin. Med. 87: 327-337.

14. Colman, R. W., A. Bagdasarian, R. C. Talamo, C. F. Scott, M. Seavey, J. A. Guimaraes, J. V. Pierce, and A. P. Kaplan. 1975. Williams trait. Human kininogen deficiency with diminished levels of plasminogen proactivator and prekallikrein associated with abnormalities of the Hageman factor-dependent pathways. J. Clin. Invest. 56: 1650-1662.

15. Habal, F. M., H. Z. Movat, and C. E. Burrowes. 1974. Isolation of two functionally different kininogens from human plasma-separation from proteinase inhibitors and interaction with plasma kallikrein. Biochem. Pharmacol. 23: 2291-2303.

16. Komiya, M., H. Kato, and T. Suzuki. 1974. Bovine plasma kininogens. I. Further purification of high molecular weight kininogen and its physicochemical properties. J. Biochem. (Tokyo). 76: 811-822.

17. Diniz, C. R., and I. V. Carvalho. 1963. A micromethod for determination of bradykininogen under several conditions. Ann. N. Y. Acad. Sci. 104: 77-89.

18. Davis, B. J. 1964. Disc electrophoresis. II. Method and application to human serum protein. Ann. N. Y. Acad. Sci. 121: 404-427.

19. Weber, K., and M. Osborn. 1969. The reliability of molecular weight determination by dodecyl sulfatepolyacrylamide gel electrophoresis. J. Biol. Chem. 244: 4406-4412.

20. Saito, H., O. D. Ratnoff, J. S. Marshall, and J. Pensky. 1973. Partial purification of plasma thromboplastin antecedent (factor XI) and its activation by trypsin. $J$. Clin. Invest. 52: 850-861.

21. McMillin, C. R., H. Saito, O. D. Ratnoff, and A. G. Walton. 1974. The secondary structure of human Hageman factor (factor XII) and its alteration by activating agents. J. Clin. Invest. 54: 1312-1322. 
22. Saito, H., and O. D. Ratnoff. 1974. Inhibition of normal clotting and Fletcher factor activity by rabbit antikallikrein antiserum. Nature (Lond.). 248: 597-598.

23. Saito, H., and M. C. Poon. 1977. Radioimmunoassay for a human plasma prekallikrein (Fletcher factor). Fed. Proc. 36: 329. (Abstr.)

24. Saito, H., O. D. Ratnoff, and J. Pensky. 1976. Radioimmunoassay of human Hageman factor (factor XII). J. Lab. Clin. Med. 88: 506-514.

25. Kaplan, A. P., and K. F. Austen. 1971. A prealbumin activator of prekallikrein. II. Derivation of activators of prekallikrein from active Hageman factor by digestion with plasmin. J. Exp. Med. 133: 696-712.

26. Cochrane, C. G., S. D. Revak, B. S. Aikin, and K. D. Wuepper. 1972. Structural characteristics and activation of Hageman factor. In Inflammation: Mechanisms and Controls. I. H. Lepow and P. A. Ward, editors. Academic Press, Inc., New York. 119-129.

27. Soltay, M. J., H. Z. Movat, and A. H. Özge-Anwar. 1971. The kinin system of human plasma. V. The probable derivation of prekallikrein activator from activated Hageman factor (XIIa). Proc. Soc. Exp. Biol. Med. 138: 952-958.

28. Kaplan, A. P., and K. F. Austen. 1970. A pre-albumin activator of prekallikrein. J. Immunol. 105: 802-811.

29. Lutcher, C. L. 1976. Reid trait: a new expression of high molecular weight kininogen (HMW-kininogen) deficiency. Clin. Res. 34: 47A. (Abstr.)

30. Matheson, R. T., D. R. Miller, M. J. Lacombe, Y. N. Han, S. Iwanaga, H. Kato, and K. D. Wuepper. 1977. Flaujeac factor deficiency. Reconstitution with highly purified bovine high molecular weight-kininogen and delineation of a new permeability-enhancing peptide released by plasma kallikrein from bovine high molecular weight-kininogen. J. Clin. Invest. 58: 1395-1406.

31. Chan, J. YC, F. M. Habal, C. E. Burrowes, and H. Z. Movat. 1977. Interaction between factor XII (Hageman factor), high molecular weight kininogen and prekallikrein. Thromb. Res. 9: 423-433.

32. Katori, M., S. Iwanaga, M. Komiya, Y. N. Han, T. Suzuki, and S. Oh-Ishi. 1975. Structure and a possible physiological function of a fragment ("histidine-rich peptide") released from bovine plasma high molecular weight kininogen by plasma kallikrein. In Kininogenases. G. L. Haberland, J. W. Rohen, G. Blumel, and P. Huber, editors. Friedrich-Karl Schattauer-Verlag, Stuttgart. 3: 11-18.

33. Ratnoff, O. D., E. W. Davie, and D. L. Mallett. 1961. Studies on the action of Hageman factor. Evidence that activated Hageman factor in turn activates plasma thromboplastin antecedent. J. Clin. Invest. 40: 803-819.

34. Nossel, H. L. 1964. Contact Phase of Blood Coagulation. Blackwell Scientific Publications Ltd., Oxford. 49-64.

35. Schiffman, S., and P. Lee. 1974. Preparation, characterization and activation of a highly purified factor XI: evidence that a hitherto unrecognized plasma activity participates in the interaction of factors XI and XII. Br. J. Haematol. 27: 101-114.

36. Heck, L. W., and A. P. Kaplan. 1974. Substrates of Hageman factor. I. Isolation and characterization of human factor XI (PTA) and inhibition of the activated enzyme by $\alpha_{1}$-anti-trypsin. J. Exp. Med. 140: 1615-1630.

37. Movat, H. A., and A. H. Özge-Anwar. 1974. The contact phase of blood coagulation: clotting factors XI and XII, their isolation and interaction. J. Lab. Clin. Med. 84: 861-878.

38. Schiffman, S., P. Lee, and R. Waldmann. 1975. Identity of contact activation cofactor and Fitzgerald factor. Thromb. Res. 6: 451-454.

39. Meier, H. L., M. Webster, C. Y. Liu, R. W. Colman, and A. P. Kaplan. 1976. Enhancement of surface dependent Hageman factor activation by high molecular weight kininogen. Fed. Proc. 35: 692. (Abstr.)

40. Griffin, J. H., and C. G. Cochrane. 1976. Mechanisms for the involvement of high M.W. kininogen in surface dependent reaction of Hageman factor. Proc. Natl. Acad. Sci. U. S. A. 73: 2554-2558.

41. Schiffman, S., and P. Lee. 1975. Partial purification and characterization of contact activation co-factor. J. Clin. Invest. 56: 1082-1092.

42. Revak, S. D., C. G. Cochrane, and J. H. Griffin. 1976. Plasma proteins necessary for the cleavage of human Hageman factor during surface activation. Fed. Proc. 35: 692. (Abstr.) 